\title{
Bacillus solisalsi sp. nov., a halotolerant, alkaliphilic bacterium isolated from soil around a salt lake
}

Correspondence

Ren Lai

rlai72@njau.edu.cn
Huan Liu, ${ }^{1,2} †$ Yu Zhou, ${ }^{3,4}+$ Rui Liu, ${ }^{3}$ Ke-Yun Zhang ${ }^{3}$ and Ren Lai ${ }^{1,3}$

\author{
${ }^{1}$ Biotoxin Units of Key Laboratory of Animal Models and Human Disease Mechanisms, Kunming \\ Institute of Zoology, Chinese Academy of Sciences, Kunming 650223, Yunnan, PR China \\ ${ }^{2}$ Graduate School of the Chinese Academy of Sciences, Beijing 100009, PR China \\ ${ }^{3}$ Key Laboratory of Microbiological Engineering of Agricultural Environment, Ministry of Agriculture, \\ Life Sciences College of Nanjing Agricultural University, Nanjing, Jiangsu, 210095, PR China \\ ${ }^{4}$ Institute of Quality and Standard for Agricultural Products, Zhejiang Academy of Agricultural \\ Sciences, Hangzhou, Zhejiang 310021, PR China
}

\begin{abstract}
A novel Gram-positive, motile, rod-shaped bacterium isolated from a saline soil in China was characterized by a polyphasic taxonomic approach. The strain, designated $\mathrm{YC}^{\top}{ }^{\top}$, was halotolerant [tolerating up to $15 \%(\mathrm{w} / \mathrm{v}) \mathrm{NaCl}$ ] and alkaliphilic (growing at a broad $\mathrm{pH}$ range of 5-13). 16S rRNA gene sequence analysis revealed that the isolate belonged to the genus Bacillus, showing highest similarity to Bacillus macauensis JCM $13285^{\top}$ (98.0\%). However, DNA-DNA hybridization indicated low levels of genomic relatedness with $B$. macauensis JCM $13285^{\top}$ (8.5\%). The major isoprenoid quinone was MK-7 and the cellular fatty acid profile consisted of significant amounts of iso- $\mathrm{C}_{15: 0}(38.6 \%)$ and anteiso- $\mathrm{C}_{15: 0}(35.9 \%)$. The predominant polar lipids were diphosphatidylglycerol, phosphatidylglycerol and phosphatidylethanolamine. The $\mathrm{G}+\mathrm{C}$ content of the genomic DNA was $41.8 \mathrm{~mol} \%$. On the basis of the polyphasic evidence from this study, strain $Y C 1^{\top}\left(=\mathrm{KCTC} 13181^{\top}=\mathrm{CGMCC} 1.6854^{\top}\right)$ should be classified as the type strain of a novel species of the genus Bacillus, for which the name Bacillus solisalsi sp. nov. is proposed.
\end{abstract}

Many haloalkaliphilic and/or alkalitolerant Bacillus species that belong to rRNA group 6 (Ash et al., 1991; Nielsen et al., 1994; Yoon et al., 2004; Nogi et al., 2005; Lim et al., 2006; Borchert et al., 2007) are widely distributed in different saline and alkaline habitats with a high $\mathrm{pH}$ and a variable (up to saturation) salt concentration. This group of bacteria has attracted much interest because its members can secrete various potentially useful enzymes (Horikoshi, 2006). Recently, some haloalkaliphilic and alkalitolerant species have been isolated from saline soil samples (Olivera et al., 2005; Nowlan et al., 2006; Lee et al., 2006; Ghosh et al., 2007). This study describes the characterization and identification of a novel halotolerant and alkaliphilic

†These authors contributed equally to this work.

Abbreviations: AL, aminolipid; APL, aminophospholipid; DPG, diphosphatidylglycerol; PE, phosphatidylethanolamine; PG, phosphatidylglycerol.

The GenBank/EMBL/DDBJ accession number for the 16S rRNA gene sequence of strain $Y C 1^{\top}$ is EU046268.

The TLC analysis of the polar lipid composition of the novel strain and $B$. macauensis and a transmission electron micrograph of cells of strain $Y C 1^{\top}$ are available as supplementary figures with the online version of this paper. species of the genus Bacillus that was isolated from a soil sample around Yuncheng Salt Lake $\left(34^{\circ} \mathrm{N} 111^{\circ} \mathrm{E}\right)$, which is located in the South Shanxi Basin of Shanxi Province, China. Yuncheng Salt Lake is the third largest sodium sulfate inland lake in the world with an area of $132 \mathrm{~km}^{2}$ and it was formed in the Quaternary Period of the Cenozoic Era. After the seas dried up and mountains formed, a large amount of saline mineral substances gathered and, after a long period of deposition and evaporation, a natural salt lake was formed.

Strain $\mathrm{YCl}^{\mathrm{T}}$ was isolated using the dilution plating technique on Luria-Bertani (LB) medium which contained the following $\left(\mathrm{g}^{-1}\right)$ : yeast extract, 5 ; tryptone, 10 ; and $\mathrm{NaCl}, 10$. The $\mathrm{pH}$ was adjusted to 7.0 with $1 \mathrm{M} \mathrm{HCl}$. The organism was incubated at $30{ }^{\circ} \mathrm{C}$ and routinely cultivated on LB agar or in LB broth at the same temperature under aerobic conditions.

The primers used for PCR amplification of the $16 \mathrm{~S}$ rRNA gene were $5^{\prime}$-AGAGTTTGATCCTGGCTCAG-3' (forward) and $5^{\prime}$-AAGGAGGTGATCCAAGCCGCA-3' (reverse), corresponding to positions $8-27$ and $1521-1540$, respectively, in the 16S rRNA gene sequence of Escherichia coli (Brosius et al., 1978). The 1424 bp sequence of strain $\mathrm{YCl}^{\mathrm{T}}$ 
was compared with sequences retrieved from GenBank using the BLAST program (http://www.ncbi.nlm.nih.gov/ blast/) to determine an approximate phylogenetic affiliation. Phylogenetic analysis was performed using the PHYLIP (Felsenstein, 1993) and MEGA version 3.1 (Kumar et al., 2001) software packages after multiple alignment of the data with CLUSTAL_X (Thompson et al., 1997). Distances (distance options according to the Kimura two-parameter model; Kimura, 1980, 1983) and clustering were based on the neighbour-joining (Saitou \& Nei, 1987) and maximum-likelihood (Felsenstein, 1981) methods. Bootstrap analysis (1000 replications) was used to evaluate the topology of the neighbour-joining tree (Felsenstein, 1985). Comparison of the 16S rRNA gene sequences showed that strain $\mathrm{YCl}^{\mathrm{T}}$ was clearly affiliated with the genus Bacillus and was most closely related to Bacillus macauensis JCM $13285^{\mathrm{T}}$ (98.0\% similarity); sequence similarities with type strains of other recognized species of the genus Bacillus were less than $96.7 \%$. A phylogenetic tree based on the neighbour-joining method indicated that strain $\mathrm{YC1}^{\mathrm{T}}$ formed a monophyletic clade adjacent to $B$. macauensis JCM $13285^{\mathrm{T}}$ with a high bootstrap resampling value of $99 \%$ (Fig. 1).

Chromosomal DNA from strain $\mathrm{YCl}^{\mathrm{T}}$ was extracted and purified according to the procedure of Yoon et al. (1996). The DNA G $+\mathrm{C}$ content, measured according to the method of Cashion et al. (1997), was $41.8 \mathrm{~mol} \%$. This value is slightly higher than that recorded for B. macauensis JCM $13285^{\mathrm{T}}(40.8 \mathrm{~mol} \%)$. DNA-DNA hybridization between strain $\mathrm{YCl}^{\mathrm{T}}$ and $B$. macauensis $\mathrm{JCM} 13285^{\mathrm{T}}$ was measured as described by De Ley et al. (1970) with the modifications described by Huß et al. (1983) and Escara \& Hutton (1980). Renaturation rates were computed with the TRANSFER.BAS program described by Jahnke (1992). At the DNA-DNA level, there was $8.5 \%$ genetic relatedness between strain $\mathrm{YC1}^{\mathrm{T}}$ and $B$. macauensis $\mathrm{JCM} 13285^{\mathrm{T}}$, which provided decisive evidence that the two strains belong to different species when the recommended threshold value of $70 \%$ DNA-DNA relatedness for the delineation of genomic species is considered (Stackebrandt et al., 2002).

Analysis of isoprenoid quinones was performed according to Komagata \& Suzuki (1987) on cells harvested from an LB broth culture incubated at $30{ }^{\circ} \mathrm{C}$ for 2 days. Peptidoglycan diamino acids were analysed in cell-wall preparations as described by Bousfield et al. (1985). The presence of meso-diaminopimelic acid as the diagnostic diamino acid of the cell-wall peptidoglycan and MK-7 as the predominant menaquinone were features that were consistent with those of numerous Bacillus species, including B. macauensis JCM $13285^{\mathrm{T}}$ (Zhang et al., 2006) and Bacillus barbaricus DSM $14730^{\mathrm{T}}$ (Täubel et al., 2003).

Polar lipids were extracted, examined by two-dimensional TLC and identified by using published procedures (Minnikin et al., 1984). Fatty acid methyl esters were prepared and identified following the instructions of the Microbial Identification system (MIDI), as described by Sasser (1990), after cells were grown on tryptic soy agar (Merck) for 2 days at $30{ }^{\circ} \mathrm{C}$. The type strain of the closely related species B. macauensis (JCM $13285^{\mathrm{T}}$ ) was also cultured under the same nutrient and temperature conditions and characterized concurrently with strain $\mathrm{YCl}^{\mathrm{T}}$. The polar lipids present in strain $\mathrm{YCl}^{\mathrm{T}}$ and $B$. macauensis were essentially similar, showing only slight quantitative differences; the polar lipid patterns for strain $\mathrm{YCl}^{\mathrm{T}}$ and B. macauensis JCM $13285^{\mathrm{T}}$ are available as Supplementary Fig. S1 in IJSEM Online. The major polar lipids present in both strains were diphosphatidylglycerol (DPG), phosphatidylglycerol (PG) and phosphatidylethanolamine (PE) and minor components were an unknown aminolipid (AL) and an unknown aminophospholipid (APL); glycolipids were not detected. The polar lipids DPG, PG, PE, AL and APL have also been detected in $B$. barbaricus DSM $14730^{\mathrm{T}}$. The absence of glycolipids in strain $\mathrm{YC1}^{\mathrm{T}}$ confirmed its close phylogenetic relatedness to $B$.

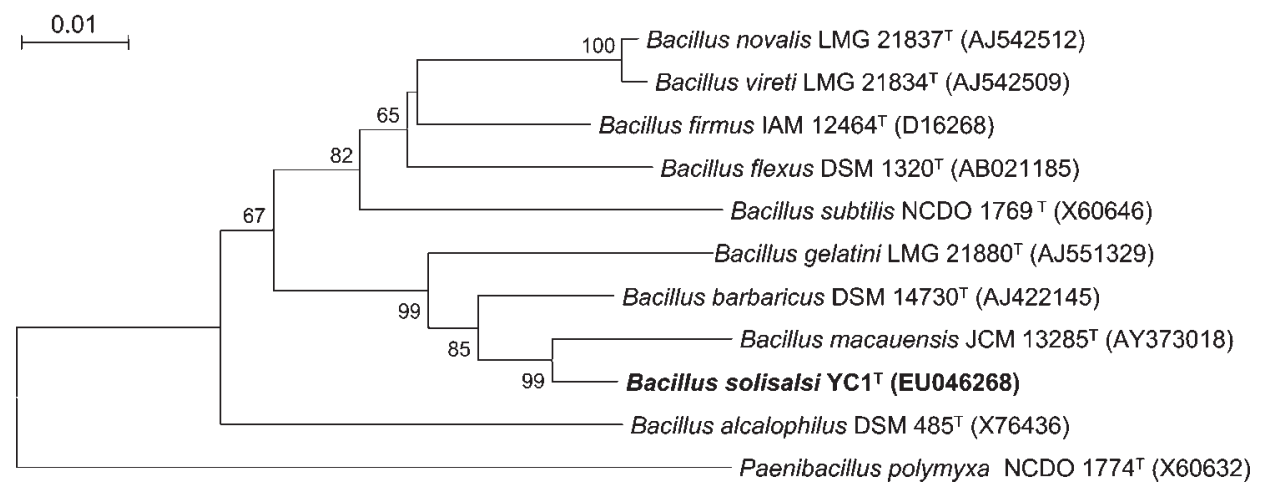

Fig. 1. Phylogenetic tree obtained by neighbour-joining analysis based on $16 \mathrm{~S}$ rRNA gene sequences showing the positions of strain $\mathrm{YC}^{\top}$ and some related members of the genus Bacillus. Only bootstrap values $>50 \%$ (expressed as percentages of 1000 resamplings) are shown at nodes. The maximum-likelihood tree showed essentially the same topology (data not shown). Bar, 0.01 substitutions per nucleotide position. 
macauensis and B. barbaricus, neither of which have glycolipids in their polar lipid profile, and its distant phylogenetic relatedness to Bacillus subtilis, which has been reported to contain glycolipids (Brundish et al., 1965; Bishop et al., 1967; Kämpfer et al., 2006).

The major cellular fatty acids of strain $\mathrm{YCl}^{\mathrm{T}}$ were iso- $\mathrm{C}_{15: 0}$ and anteiso- $\mathrm{C}_{15: 0}$, comprising about 38.6 and $35.9 \%$, respectively, of the total fatty acid content. As shown by Kämpfer (1994), the predominance of 14- to 17-carbon iso- and anteiso-branched fatty acids is typical of members of the genus Bacillus. The fatty acid profile of strain $\mathrm{YCl}^{\mathrm{T}}$ was similar to those of its close relatives, $B$. macauensis JCM $13285^{\mathrm{T}}$, B. barbaricus DSM $14730^{\mathrm{T}}$ and Bacillus gelatini LMG $21880^{\mathrm{T}}$, but the fatty acid compositions were somewhat different (Table 1).

Cell morphology and motility were examined using light microscopy (model BH2; Olympus) and transmission electron microscopy (model H-7650; Hitachi) after $48 \mathrm{~h}$ growth on LB agar at $30{ }^{\circ} \mathrm{C}$. For electron microscopic observation, cells were air-dried and negatively stained with $1 \%(\mathrm{w} / \mathrm{v})$ phosphotungstic acid (see Supplementary Fig. S2 available in IJSEM Online). Gram-staining and analysis of endospore-forming features were performed according to the method described by Smibert \& Krieg (1994). Growth at different temperatures and $\mathrm{pH}$ was investigated as described by Xu et al. (2005) using LB as the basal medium. $\mathrm{NaCl}$ tolerance was tested at concentrations between 0 and $20 \%(\mathrm{w} / \mathrm{v})$ in combination with LB medium. Growth was tested on nutrient agar, Simmons' citrate agar, cetrimide agar and MacConkey agar. Oxidase, catalase and phenylalanine deaminase activities and hydrolysis of casein, gelatin, Tweens 80 and 20, carboxylmethylcellulose, aesculin, tyrosine, DNA and starch were investigated as described by Smibert \& Krieg (1994). Acid production from carbohydrates was determined using the medium and method described by Yamaguchi \& Yokoe (2000). Single carbon source utilization studies were carried out as described by Liu et al. (2008). Sensitivity

Table 1. Fatty acid content (\%) of strain $\mathrm{YC}^{\top}$ and related species of the genus Bacillus

Strains: $1, \mathrm{YC1}^{\mathrm{T}}$ (data from present study); 2, B. macauensis JCM $13285^{\mathrm{T}}$ (present study); 3, B. barbaricus DSM $14730^{\mathrm{T}}$ (Täubel et al., 2003); 4, B. gelatini LMG $21880^{\mathrm{T}}$ (De Clerck et al., 2004).

\begin{tabular}{|c|c|c|c|c|}
\hline Fatty acid & 1 & 2 & 3 & 4 \\
\hline iso- $\mathrm{C}_{14: 0}$ & 0.7 & 2.3 & 9.4 & 0 \\
\hline $\mathrm{C}_{14: 0}$ & 0.7 & 1.4 & 0.9 & 0 \\
\hline iso- $_{15: 0}$ & 38.6 & 25.5 & 19.0 & 60 \\
\hline anteiso- $\mathrm{C}_{15: 0}$ & 35.9 & 62.3 & 42.8 & 9 \\
\hline iso- $\mathrm{C}_{16: 0}$ & 2.5 & 2.8 & 6.0 & 4 \\
\hline $\mathrm{C}_{16: 0}$ & 3.4 & 0 & 2.0 & 2 \\
\hline iso- $\mathrm{C}_{17: 0}$ & 7.7 & 5.2 & 0.0 & 13 \\
\hline anteiso- $\mathrm{C}_{17: 0}$ & 10.0 & 0.2 & 2.6 & 10.0 \\
\hline
\end{tabular}

to antibiotics was tested using the diffusion method as described by Park et al. (2007) on LB agar at $30{ }^{\circ} \mathrm{C}$ with antibiotic filter-paper discs $(8 \mathrm{~mm}$ diameter; Sanofi Pasteur). All tests were performed at $30{ }^{\circ} \mathrm{C}$ and properties were recorded after 2 days. Additional biochemical features were tested using API 20E kits (bioMérieux) according to the instructions of the manufacturer. Phenotypic characteristics of strain $\mathrm{YCl}^{\mathrm{T}}$ are shown in the species description and in Table 2. As shown in Table 2, the novel isolate can be readily differentiated from its closest phylogenetic relatives in the genus Bacillus by several phenotypic properties.

On the basis of the above evidence, it is proposed that strain $\mathrm{YC}^{\mathrm{T}}$ should be classified in the genus Bacillus as the type strain of a novel species, for which the name Bacillus solisalsi sp. nov. is proposed.

\section{Description of Bacillus solisalsi sp. nov.}

Bacillus solisalsi (so.li.sal'si. L. neut. n. solum -i soil; L. adj. salsus - a -um salty; N.L. gen. n. solisalsi of a salty soil).

Table 2. Differential characteristics of strain $\mathrm{YC}^{\top}$ and related species of the genus Bacillus

Strains: $1, \mathrm{YCl}^{\mathrm{T}}$ (data from present study); 2, B. macauensis JCM $13285^{\mathrm{T}}$ (Zhang et al., 2006); 3, B. barbaricus DSM $14730^{\mathrm{T}}$ (Täubel et al., 2003); 4, B. gelatini LMG $21880^{\mathrm{T}}$ (De Clerck et al., 2004). + , Positive; -, negative; V, results vary between references; ND, no data available.

\begin{tabular}{|lcccc|}
\hline Characteristic & $\mathbf{1}$ & $\mathbf{2}$ & $\mathbf{3}$ & $\mathbf{4}$ \\
\hline Growth at $47^{\circ} \mathrm{C}$ & + & - & - & + \\
Growth in NaCl: & & & & \\
$5 \%$ & + & - & - & + \\
$10 \%$ & + & - & - & + \\
Gelatin hydrolysis & - & + & $\mathrm{ND}$ & + \\
Utilization of: & & & & \\
Cellobiose & - & + & - & $\mathrm{V}$ \\
D-Fructose & + & $\mathrm{V}$ & + & + \\
D-Galactose & - & + & - & + \\
D-Glucose & - & + & + & + \\
Inositol & - & + & - & + \\
Maltose & - & + & + & + \\
D-Mannitol & + & + & - & + \\
N-Acetyl-D-glucosamine & - & $\mathrm{V}$ & + & + \\
Pyruvate & - & + & + & $\mathrm{ND}$ \\
L-Rhamnose & - & + & - & $\mathrm{ND}$ \\
D-Ribose & - & + & + & + \\
Salicin & + & + & - & - \\
D-Sorbitol & - & $\mathrm{V}$ & - & $\mathrm{ND}$ \\
Sucrose & - & + & - & $\mathrm{ND}$ \\
Trehalose & + & - & + & + \\
D-Xylose & + & $\mathrm{V}$ & - & + \\
DNA G+C content (mol\%) & 41.8 & 40.8 & $\mathrm{ND}$ & 41.5 \\
& & & & \\
\hline
\end{tabular}


Cells are Gram-positive, endospore-forming, facultatively anaerobic, motile rods bearing a single lateral flagellum. Cells are $0.9 \mu \mathrm{m}$ wide and 2.5-3.0 $\mu \mathrm{m}$ long. Endospores are ellipsoidal and form subterminally in swollen sporangia. After 2 days incubation on LB agar, colonies are 0.5$1.0 \mathrm{~mm}$ in diameter, cream-coloured, opaque, circular, smooth and convex. Grows at $15-53{ }^{\circ} \mathrm{C}$ (optimum, 35$42{ }^{\circ} \mathrm{C}$ ) and $\mathrm{pH} 5-13$ (optimum, $\mathrm{pH} 7-10$ ). Tolerates up to $15 \% \mathrm{NaCl}$. Growth occurs on nutrient agar, but not on Simmons' citrate agar, cetrimide agar or MacConkey agar. Catalase- and oxidase-positive. Phenylalanine deaminasenegative. In API $20 \mathrm{E}$ tests, positive for $\beta$-galactosidase, lysine decarboxylase and Voges-Proskauer reaction. Negative for arginine dihydrolase, arginine decarboxylase, ornithine decarboxylase, indole and $\mathrm{H}_{2} \mathrm{~S}$ production, urease and nitrate reduction. Starch, DNA, tyrosine, Tween 20, aesculin and casein are hydrolysed, but Tween 80 , gelatin and carboxylmethylcellulose are not. Acid is produced from trehalose, salicin and D-fructose. Utilizes Dxylose, D-fructose, D-mannose, trehalose, D-mannitol, Larabinose and salicin, but not D-lactose, sucrose, D-galactose, D-glucose, maltose, melibiose, turanose, cellobiose, D-ribose, melezitose, raffinose, L-rhamnose, L-sorbose, adonitol, Larabitol, i-erythritol, xylitol, D-sorbitol, inositol, dextrin, glycerol, acetate, gluconate, inulin, amygdalin, $\mathrm{N}$-acetyl-Dglucosamine, pyruvate or methyl $\alpha$-glucoside. Sensitive to streptomycin $(10 \mu \mathrm{g})$, penicillin $\mathrm{G}$ (10 IU), ampicillin $(10 \mu \mathrm{g})$, chloramphenicol $(30 \mu \mathrm{g})$, erythromycin $(15 \mu \mathrm{g})$, tetracycline $(30 \mu \mathrm{g})$, ofloxacin $(5 \mu \mathrm{g})$, amoxicillin $(10 \mu \mathrm{g})$, cefamezin $(30 \mu \mathrm{g})$, rifampicin $(5 \mu \mathrm{g})$, gentamicin $(10 \mu \mathrm{g})$, ceftazidime $(30 \mu \mathrm{g})$, vancomycin $(30 \mu \mathrm{g})$, kanamycin $(30 \mu \mathrm{g})$, carbenicillin $(100 \mu \mathrm{g})$ and polymyxin $\mathrm{B}(30 \mu \mathrm{g})$. The diagnostic diamino acid of the cell-wall peptidoglycan is meso-diaminopimelic acid and MK-7 is the predominant quinone. The cellular fatty acid profile consists of significant amounts of $\mathrm{C}_{15}$ branched-chain acids, iso- $\mathrm{C}_{15: 0}$ and anteiso$\mathrm{C}_{15: 0}$. Major polar lipids are DPG, PG and PE; APL and AL are minor components.

The type strain, $\quad \mathrm{YCl}^{\mathrm{T}} \quad\left(=\mathrm{KCTC} \quad 13181^{\mathrm{T}}=\mathrm{CGMCC}\right.$ $\left.1.6854^{\mathrm{T}}\right)$, was isolated from a soil sample taken from the Yuncheng Salt Lake in the Shanxi Province, PR China. The DNA G $+\mathrm{C}$ content of the type strain is $41.8 \mathrm{~mol} \%$.

\section{Acknowledgements}

This work was supported by the grants of NSFC30830021 and MSOT0901291033. We are also grateful to Isao Yumoto for excellent technical assistance.

\section{References}

Ash, C., Farrow, J. A. E., Wallbanks, S. \& Collins, M. D. (1991). Phylogenetic heterogeneity of the genus Bacillus revealed by comparative analysis of small-subunit-ribosomal RNA sequences. Lett Appl Microbiol 13, 202-206.

Bishop, D. G., Rutberg, L. \& Samuelsson, B. (1967). The chemical composition of the cytoplasmic membrane of Bacillus subtilis. Eur J Biochem 2, 448-453.
Borchert, M. S., Nielsen, P., Graeber, I., Kaesler, I., Szewzyk, U., Pape, T., Antranikian, G. \& Schäfer, T. (2007). Bacillus plakortidis sp. nov. and Bacillus murimartini sp. nov., novel alkalitolerant members of rRNA group 6. Int J Syst Evol Microbiol 57, 28882893.

Bousfield, I. J., Keddie, R. M., Dando, T. R. \& Shaw, S. (1985). Simple rapid methods of cell wall analysis as an aid in the identification of aerobic coryneform bacteria. In Chemical Methods in Bacterial Systematics, pp. 221-236. Edited by M. Goodfellow \& D. E. Minnikin. London: Academic Press.

Brosius, J., Palmer, M. L., Kennedy, P. J. \& Noller, H. F. (1978). Complete nucleotide sequence of a $16 \mathrm{~S}$ ribosomal RNA gene from Escherichia coli. Proc Natl Acad Sci U S A 75, 4801-4805.

Brundish, D. E., Shaw, N. \& Baddiley, J. (1965). The occurrence of glycolipids in Gram-positive bacteria. Biochem J 95, 21c-22c.

Cashion, P., Holder-Franklin, M. A., McCully, J. \& Franklin, M. (1997). A rapid method for the base ratio determination of bacterial DNA. Anal Biochem 81, 461-466.

De Clerck, E., Rodríguez-Díaz, M., Vanhoutte, T., Heyrman, J., Logan, N. A. \& De Vos, P. (2004). Anoxybacillus contaminans sp. nov. and Bacillus gelatini sp. nov., isolated from contaminated gelatin batches. Int J Syst Evol Microbiol 54, 941-946.

De Ley, J., Cattoir, H. \& Reynaerts, A. (1970). The quantitative measurement of DNA hybridization from renaturation rates. Eur $J$ Biochem 12, 133-142.

Escara, J. F. \& Hutton, J. R. (1980). Thermal stability and renaturation of DNA in dimethyl sulfoxide solutions: acceleration of renaturation rate. Biopolymers 19, 1315-1327.

Felsenstein, J. (1981). Evolutionary trees from DNA sequences: a maximum likelihood approach. J Mol Evol 17, 368-376.

Felsenstein, J. (1985). Confidence limits on phylogenies: an approach using the bootstrap. Evolution 39, 783-791.

Felsenstein, J. (1993). PHYLIP (phylogeny inference package), version 3.5c. Distributed by the author. Department of Genome Sciences, University of Washington, Seattle, USA.

Ghosh, A., Bhardwaj, M., Satyanarayana, T., Khurana, M., Mayilraj, S. \& Jain, R. K. (2007). Bacillus lehensis sp. nov., an alkalitolerant bacterium isolated from soil. Int J Syst Evol Microbiol 57, 238-242.

Horikoshi, K. (2006). Alkaliphiles. Tokyo: Kodansha.

Huß, V. A. R., Festl, H. \& Schleifer, K. H. (1983). Studies on the spectrophotometric determination of DNA hybridization from renaturation rates. Syst Appl Microbiol 4, 184-192.

Jahnke, K. D. (1992). BASIC computer program for evaluation of spectroscopic DNA renaturation data from GILFORD SYSTEM 2600 spectrophotometer on a PC/XT/AT type personal computer. J Microbiol Methods 15, 61-73.

Kämpfer, P. (1994). Limits and possibilities of total fatty acid analysis for classification and identification of Bacillus species. Syst Appl Microbiol 17, 86-98.

Kämpfer, P., Rossell-Mora, R., Falsen, E., Busse, H.-J. \& Tindall, B. J. (2006). Cohnella thermotolerans gen. nov., sp. nov., and classification of 'Paenibacillus hongkongensis' as Cohnella hongkongensis sp. nov. Int J Syst Evol Microbiol 56, 781-786.

Kimura, M. (1980). A simple method for estimating evolutionary rates of base substitutions through comparative studies of nucleotide sequences. J Mol Evol 16, 111-120.

Kimura, M. (1983). The Neutral Theory of Molecular Evolution. Cambridge: Cambridge University Press.

Komagata, K. \& Suzuki, K. (1987). Lipid and cell-wall analysis in bacterial systematics. Methods Microbiol 19, 161-207. 
Kumar, S., Tamura, K., Jakobsen, I.-B. \& Nei, M. (2001). MEGA2: Molecular Evolutionary Genetics Analysis software. Bioinformatics 17, 1244-1245.

Lee, J.-C., Lim, J.-M., Park, D.-J., Jeon, C. O., Li, W.-J. \& Kim, C.-J. (2006). Bacillus seohaeanensis sp. nov., a halotolerant bacterium that contains L-lysine in its cell wall. Int J Syst Evol Microbiol 56, 1893 1898.

Lim, J.-M., Jeon, C. O. \& Kim, C.-J. (2006). Bacillus taeanensis sp. nov., a halophilic Gram-positive bacterium from a solar saltern in Korea. Int J Syst Evol Microbiol 56, 2903-2908.

Liu, H., Liu, R., Yang, S.-Y., Gao, W.-K., Zhang, C.-X., Zhang, K.-Y. \& Lai, R. (2008). Flavobacterium anhuiense sp. nov., isolated from field soil. Int J Syst Evol Microbiol 58, 756-760.

Minnikin, D. E., O'Donnell, A. G., Goodfellow, M., Alderson, G., Athalye, M., Schaal, A. \& Parlett, J. H. (1984). An integrated procedure for the extraction of bacterial isoprenoid quinones and polar lipids. J Microbiol Methods 2, 233-241.

Nielsen, P., Rainey, F. A., Outtrup, H., Priest, F. G. \& Fritze, D. (1994). Comparative 16S rDNA sequence analysis of some alkaliphilic bacilli and the establishment of a sixth rRNA group within the genus Bacillus. FEMS Microbiol Lett 117, 61-66.

Nogi, Y., Takami, H. \& Horikoshi, K. (2005). Characterization of alkaliphilic Bacillus strains used in industry: proposal of five novel species. Int J Syst Evol Microbiol 55, 2309-2315.

Nowlan, B., Dodia, M. S., Singh, S. P. \& Patel, B. K. C. (2006). Bacillus okhensis sp. nov., a halotolerant and alkalitolerant bacterium from an Indian saltpan. Int J Syst Evol Microbiol 56, 1073-1077.

Olivera, N., Siñeriz, F. \& Breccia, J. D. (2005). Bacillus patagoniensis sp. nov., a novel alkalitolerant bacterium from the rhizosphere of Atriplex lampa in Patagonia, Argentina. Int J Syst Evol Microbiol 55, 443-447.

Park, M., Ryu, S. H., Thi Vu, T.-H., Ro, H.-S., Yun, P.-Y. \& Jeon, C. O. (2007). Flavobacterium defluvii sp. nov., isolated from activated sludge. Int J Syst Evol Microbiol 57, 233-237.

Saitou, N. \& Nei, M. (1987). The neighbor-joining method: a new method for reconstructing phylogenetic trees. Mol Biol Evol 4, 406425 .
Sasser, M. (1990). Identification of bacteria by gas chromatography of cellular fatty acids. USFCC Newsl 20, 16.

Smibert, R. M. \& Krieg, N. R. (1994). Phenotypic characterization. In Methods for General and Molecular Bacteriology, pp. 607-654. Edited by P. Gerhardt, R. G. E. Murray, W. A. Wood \& N. R. Krieg. Washington, DC: American Society for Microbiology.

Stackebrandt, E., Frederiksen, W., Garrity, G. M., Grimont, P. A. D., Kämpfer, P., Maiden, M. C. J., Nesme, X., Rosselló-Mora, R., Swings, J. \& other authors (2002). Report of the ad hoc committee for the reevaluation of the species definition in bacteriology. Int J Syst Evol Microbiol 52, 1043-1047.

Täubel, M., Kämpfer, P., Buczolits, S., Lubitz, W. \& Busse, H.-J. (2003). Bacillus barbaricus sp. nov., isolated from an experimental wall painting. Int J Syst Evol Microbiol 53, 725-730.

Thompson, J. D., Gibson, T. J., Plewniak, F., Jeanmougin, F. \& Higgins, D. G. (1997). The CLUSTAL_X windows interface: flexible strategies for multiple sequence alignment aided by quality analysis tools. Nucleic Acids Res 25, 4876-4882.

Xu, P., Li, W.-J., Tang, S.-K., Zhang, Y.-Q., Chen, G.-Z., Chen, H.-H., Xu, L.-H. \& Jiang, C.-L. (2005). Naxibacter alkalitolerans gen. nov., sp. nov., a novel member of the family 'Oxalobacteraceae' isolated from China. Int J Syst Evol Microbiol 55, 1149-1153.

Yamaguchi, S. \& Yokoe, M. (2000). A novel protein-deamidating enzyme from Chryseobacterium proteolyticum sp. nov., a newly isolated bacterium from soil. Appl Environ Microbiol 66, 3337-3343.

Yoon, J.-H., Kim, H., Kim, S.-B., Kim, H.-J., Kim, W. Y., Lee, S. T., Goodfellow, M. \& Park, Y.-H. (1996). Identification of Saccharomonospora strains by the use of genomic DNA fragments and rRNA gene probes. Int J Syst Bacteriol 46, 502-505.

Yoon, J.-H., Kim, I.-G., Kang, K. H., Oh, T.-K. \& Park, Y.-H. (2004). Bacillus hwajinpoensis sp. nov. and an unnamed Bacillus genomospecies, novel members of Bacillus rRNA group 6 isolated from sea water of the East Sea and the Yellow Sea in Korea. Int J Syst Evol Microbiol 54, 803-808.

Zhang, T., Fan, X., Hanada, S., Kamagata, Y. \& Fang, H. H. P. (2006). Bacillus macauensis sp. nov., a long-chain bacterium isolated from a drinking water supply. Int J Syst Evol Microbiol 56, 349-353. 